\title{
REVISING THE BLACK DECOLONIALIZATION PROCESS: KENDRICK LAMAR'S DAMN. AND THE POETICS OF VIOLENCE
}

\begin{abstract}
Frantz Fanon's writings on decolonization have constantly been read as a call for violence against oppressive colonial rulings. The choice that the subjugated individual must make between remaining a victim or using the colonial violence against those who originally initiated it represents one of Fanon's main arguments in The Wretched of the Earth. Drawing on Kendrick Lamar's music album DAMN. (2017), this article aims to show how the rapper rewrites the decolonization process in a poetic way, using metaphors, hyperboles and allegories. The interactions between white and Black individuals that Lamar examines in his songs provide an answer to Fanon's urge to choose. Moving beyond the Fanonian binary thinking (Black/white, colonizer/colonized), DAMN. provides an insight on how whiteness and Blackness co-inhabit a space full of violent encounters. While presenting an X-ray image of the present-day United States of America, Lamar does not offer an answer on the questions on racism, but he delivers a vivid picture of the outcomes of personal choices, collective failures and perpetual violence.
\end{abstract}

Keywords: Frantz Fanon; decolonization; rap music; violence; Black.

Much has been debated around the role rap music has in the understanding of Black identity and culture and, more importantly, around the violence that accompanies this specific musical genre. In 2018, when Kendrick Lamar was awarded the Pulitzer Prize for music, he became the first non-jazz or classical artist to receive the award. According to the Pulitzer committee, Lamar's 2017 album DAMN. is "a virtuosic song collection unified by its vernacular authenticity and rhythmic dynamism that offers affecting vignettes capturing the

* University of Bucharest; Romania. 
complexity of modern African-American life" ${ }^{\prime 5}$. On DAMN., Lamar builds a parable on the aftermath of decolonization and its subsequent violence.

I this article I aim to read Kendrick Lamar's DAMN. as a revision of Frantz Fanon's writings on decolonization, as they arise in The Wretched of the Earth. Firstly, I will focus on Fanon's conceptions on the necessity of violence in the decolonization process. Although he sees violence as the moving force that pushes the revolution against colonialism forward, he does not argue for an arbitrary form of violence, but he rather calls for an almost systematic one. At the same time, he makes a case against violence without a cause, claiming that the dangers which accompany this form of revolting are both physical and psychological. Secondly, I will argue how Lamar follows Fanon's footsteps when he closely examines the horizon of the Black decolonization act by pleading for a form of violence that allows him to go beyond the Fanonian binary mode of operating - black/white; colonized/colonizer. Finally, I will argue that, despite Fanon's ambiguities and very problematic claims, his writings on decolonization still provide relevant observations on the psychological effects of colonialism and its aftermath.

On DAMN., Lamar "locates salvation within the inescapable human boundedness between America's DAMNed of the earth and the colonizing white body" (Lewellyn-Taylor and Jones 248) and he does not refrain from seeing their inability to understand each other and the cause of destruction for both presumably opposing sides: "Tell me when destruction gonna be my fate / Gonna be your fate, gonna be our faith" (DNA). Destruction is not merely an ending, but rather a possibility for salvation for both sides, which creates an inevitable bond between Black individuals and white individuals, which represents

the meeting of two forces, opposed to each other by their very nature, which in fact owe their originality to that sort of substantification which results from and is nourished by the situation in the colonies. (Fanon 27-8)

Frantz Fanon, who held an important position in the Algerian war against French colonization, has written extensively on the psychological effects of colonization, drawing on psychoanalytical French theorists, while he was

\footnotetext{
${ }^{5}$ According to the Pulitzer website.
} 
University of Bucharest Review $\propto$ Vol. X/2020, no. 1 (new series)

Re-writing, Re-imagining the Past (I)

strongly influenced by Aimé Césaire. The Wretched of the Earth has influenced both African and African American social and theoretical movements. Originally titled Les damnés de la terre in 1961, it deals with an intricate subject: violence as a mandatory force in the struggle against colonialism. Although it has generated much controversy and was described as a work of "barbarism and terrorism" (Smith 32), Fanon's pivotal book offers an opportunity to look at the anticolonial violence through the lenses of systematic revolting, which has a clear and definite purpose.

For Fanon, the first encounter between the colonizer and the colonized "was marked by violence" (Fanon 28) and this continues to represent a key factor when one attempts to interrogate the dynamics that shape this relation. The convoluted oscillations between Black and white existence are visible on DAMN. from the very first track, $B L O O D$, where Kendrick Lamar uses storytelling as he describes an encounter with a blind woman who shot him when he tried to help her, which forces him into asking "Is it wickedness?/Is it weakness?", a question that also appears on another songs and becomes the leitmotiv of the album. Similar to other apparent oppositions Lamar makes on this album, the wickedness/weakness one seems to be not a contradiction, but rather the two are both part of white and Black existence, as they bear the opportunity for violence to either develop or cease to exist. Not randomly does DAMN. start with this song, but, similar to what Fanon argued, for both the colonizer, and the colonized, wickedness and weakness lead to a collapse of the psyche (Fanon, Black Skins). Precisely for this reason, the process of decolonization cannot happen otherwise, but under the sign of violence. As he names the many forms of physical and psychological brutality that the colonizer has exercised on the colonized psyche, Fanon sees the "the denial of educational opportunity, and by the forced segregation in living arrangements" (Fairchild 192) as the force that helps maintaining the inequality between the two. The colonizer achieves this subjugation through a "colonial vocabulary" (Fanon 33), which allows them to create new living conditions, in which the native is permanently dehumanised and stripped of their national culture and heritage.

The concept of 'heritage' seems to be lurking around DAMN. from the second song of the album, titled DNA. Here Lamar discusses the binary oppositions of the Black psyche, which, despite what seems to be an initial separation from the white psyche, is in fact what binds the two forever. The word 'DNA' has a metaphorical meaning in the song, as it encompasses the stereotypes 
surrounding African-Americans.

Realness, I just kill shit 'cause it's in my DNA “...”

Cocaine quarter piece, got war and peace inside my DNA

I got power, poison, pain and joy inside my DNA “..."

I got dark, I got evil that rot inside my DNA

I got off, I got troublesome heart inside my DNA

I just win again, then win again like Wimbledon, I serve.

It is on this track that Lamar moves between the stereotypes surrounding Black existence and the heritage that is carried by African-Americans, one that could determine their destiny. Lamar uses the metaphor of a biological function that makes individuals be genetically predisposed towards specific acts in an ironical way, which allows him to rewrite the convoluted history of 'Blackness' and moreover the many ramifications it has today. However, the tonal shift "I just win again" functions as a reminder that the initial status could change direction, allowing not only him, but other African-Americans to move beyond the existent stereotypes. DAMN. seems to be a profoundly personal recollection of Black existence which is painfully interwoven with white existence. Lamar shows the many ties that bind the two using the metaphor of 'heritage' of human condition, also in the form of an opposition. Discussing the white 'heritage', the rapper states "Daddy prolly snitched, heritage inside your DNA", evoking the many betrayals encountered by Black people during and after slavery. For Lamar, snitching and betrayal represent two components of white DNA, while for the Black individual 'heritage' bears a different meaning: "I got/Loyalty, got royalty inside my DNA/This is my heritage, all I'm inheritin' “..." /Money and power, the mecca of marriages" (DNA). It seems that what differentiates the white psyche from Black psyche is their respective understanding of loyalty. It is particularly through his loyalty towards the community that he manages to achieve what he calls "the mecca of marriages" (DNA). Nonetheless, around the middle of the song, one can hear journalist Geraldo Rivera's statement that "hip hop has done more damage to young African Americans than racism in recent years", which echoes throughout the whole album, as the statement that drive Lamar into attempting to release himself (and the community) from the systemic 
oppression, which is accompanied by multiple forms of violence ${ }^{6}$. This echoes a statement made by Fanon, who claimed that the native is "declared insensible to ethics; he represents not only the absence of values, but also the negation of values. He is, dare to admit, the enemy of values, and in this sense he is the absolute evil" (Fanon 32). Unlike Fanon, Lamar does not stay in the dualistic opposition between good and evil as the pillar on which the Black individual is denied ethical and moral values. Instead he argues for a non-compromising way of engaging with the struggle against white individuals, while he finds a way to answer to the many forms of violence - "Phone never on/I don't compromise, I just penetrate" (DNA). The encounters between white and Black individuals are permanently under the sign of violence and for Lamar, the violence exercised against the Black community is more than often one that occurs at a linguistic level. Here again Fanon's writings will prove worth investigating, as he claims that

those speeches seem like collections of dead words; those values which seemed to uplift the soul are revealed as worthless, simply because they have nothing to do with the concrete conflict in which the people is engaged. (Fanon 36)

Hence, Fanon seems to suggest that the distance between colonized and colonizer is once again made visible by the vocabulary used by the colonized and the ways they attempt to show a form of solidarity of the subjugated people. Through speech, the settler "indicates that he himself is the extension of that mother country" (Fanon 40) and, by doing this, they provide, anew, the instrument that enables one to enslave a people. The feeling of 'closeness' between the two is an apparent one, as it can never be possible for the two to share the same vocabulary. Concurrently, the native is demanded that they keep their minority position, "to stay in his place, and not to go beyond certain limits" (40), without any attempt to achieve a higher role in the society. According to Fanon, this forces them to have once specific goal: "the dreams of the native are always of muscular prowess; his dreams are of action and of aggression" (40).

For Lamar, this dream is, in fact, a lucid dream, as "he is lucid to his makeup, his social-psychic meaning, and in this way, Lamar is aware of the illusion of

${ }^{6}$ See Geraldo Rivera's statement above as an example of psychological violence. 
authority - the effort to simplify existence so as to tame it" (Pinn 236). Arguing that "what happens on Earth stays on Earth" (ELEMENT), Lamar seems to be at the same time denouncing and restating his religious beliefs that are present on almost all other tracks on DAMN and turns towards more earthly things, such as authority, which he sees as a deception. As Fanon suggests, there is a choice that the colonizer must make: to accept colonization and the ensuing violence, or to take this foreign form of violence against those who originally initiated it against indigenous people. Here again once notices Fanon's binary mode of operating, as for him there is no middle way, the colonized must make a clear choice. Differently from the Fanonian thought, on ELEMENT, Lamar attempts to simplify existence by fully committing "to die for this shit" (ELEMENT), turning towards earthly things, instead of making a choice regarding how he may use violence. Nonetheless, the persistence of loyalty for the community is still a recurring theme, similar to DNA: "I don't do it for the 'Fram, I do it for Compton" (ELEMENT). Hence, he chooses a third option, which also enables Fanon's ideal of a revolution with a clear cause: the Black community becomes the drive that motivates him into moving further on his quest. What must be told is that Compton, a city in California, where many rap artists were born, is, for Lamar, the place where his first encounter with violence has occurred. Frequently mentioned on his songs, both on DAMN., as on his older albums, it represents a living connection he has with the aftermath of slavery and the consequences of perpetual violence, particularly against African-Americans. At the same time, the rapper seems to be fully aware of what he needs to do, stating "They won't take me out my element" (ELEMENT) after suggesting again a series of stereotypes concerning Black existence. And yet, the verse "Fake my own death, go to Cuba, that's the only option" appears to show what he sees as a counter-reaction to the violent response. Lamar refuses to occupy the position of a victim, instead he engages with his own subjecthood in the quest of 'fighting back'.

In the middle of Lamar's personal pursuit of justice, the body seems to hold the centre together. For Fanon, it is the colonized body that is at stake upon raising against colonialism, for the psychological effects and affects of enslavement are rooted in the bodily experience. It is, thus, not illogical that the colonized will manifest against the settler in an aggressive and brutal way, regardless of the possible outcomes on their own life. The arguments presented by a historical perspective may prove their utility, but the purpose of this article lies beyond this argumentation. I argue that it is not only due to the historical 
situation that the Black dreams of revolting against the oppressor, but rather the ever-returning past that prevents them from moving past the colonization period. Similar, to some extent, to Johann Baptist Metz's concept of dangerous memories, which are "memories which make demands of us" (Metz 109), Fanon argues that the consequences that colonialism has on the individual psyche allow them to "manifest this aggressiveness which has been deposited in his bones against his own people" (40), while also stating that "this is the period when the niggers beat each other up" (40). The memory of colonization demands formerly enslaved individuals to search for a way of responding to the violence that was inflicted on them.

On GOD, Lamar offers a performance of such a 'dangerous memory'. While stating "This is what God feels like" (GOD), the rapper turns again to his lucid dream: "Ever since a young man (since a young man)/All I wanna be was a gunman (was a gunman)" (GOD). The vivid affirmation on his desires shows Lamar's own aggressivity, which arises from the precise position of God. As almighty, he has the opportunity to keep on "laughin' to the bank" (GOD), but also to turn his back to possessions, which he saw as "the mecca of marriages" $(D N A)$ earlier, in another example of the inner contradictions which appear on $D A M N$. Concurrently he speaks directly to white people, stating "Ask for a piece of mine, you charged me for it" (GOD), indicating the heavy price he had to pay in order to be able to feel like a God, as he argues. It is memories of slavery and subjugation that demand him to engage in a fight which is not only aimed towards white people, but rather to everybody who was against him. Across the whole album, it seems like Lamar is at war with the whole world, until on the very last track, which resembles a testimony, where he claims "It was always me vs. the world/Until I found it's me vs. me" (DUCKWORTH).

The long and necessary discussion this specific form of violence has, according to Fanon, been rooted in the impossible, yet urgent, revolution that the native desires, but he has very few means through which they can achieve it: "there is no compromise, no possible coming to terms; colonization and decolonization are simply a question of relative strength" (47). Fanon rejects nonviolence as "the idea of compromise is very important in the phenomenon of decolonization" (48), although it fails to deliver, but rather it becomes a way for the oppressor to support their hegemony. It is precisely because non-violence is mostly preached by the same people who maintain the colonial ways that it cannot provide any form of liberation for the oppressed people. It speculates the 
idea that cohabitation can be possible for both sides, if they agree to compromise. However, this compromise is almost never one that allows the settlers and the colonized to obtain the same sits at the table.

The specificity of anticolonial violence, as Fanon argues, is that it "does not intend to promote physical violence (though it is not wholly discouraged" (Lewellyn-Taylor and Jones 249), but it "fulfils for the native a role that is not simply informatory, but also operative" (Fanon 55). On one side, this violence also works on the colonist, forcing them into modifying their behaviour, sometimes even into fear of the colonized. On the other side, it permits the colonizer to use the violence that "is just under the skin" (55), capturing even the atmosphere that surrounds the native. Rightfully seen as controversial, Fanon's argument that "the development of violence among the colonized people will be proportionate to the violence exercised by the threatened colonial regime" (69) raises the question on the legitimacy of violence. For how can violence be legitimized? It is here that those familiar with Fanon's work will remember his claim that the "people must know where they are going, and why" (156). Hence, Fanon argues for a systematic anticolonial violence. He pleads for a counterreaction that will allow the indigenous people to rethink the concept of revolting and it is the form of this counter-reaction that both the settler and the colonized will realize that

the practice of violence binds them together as a whole, since each individual forms a violent link in the great chain, a part of the great organism of violence that has surged upwards in reaction to the settler's violence in the beginning. (73)

Thus, the settler and the colonized are inextricably interwoven in their use of violence, which they exercise against each other, but which may also become a form of violence against the self. At the same, Fanon claims that "at the level of individuals, violence is a cleansing force. It frees the native from his inferiority complex and from his despair and inaction" (74). Hence, for the Martinican psychiatrist, it is only through violence that the native may have the chance to regain not only his freedom, but also his notion on identity. Perhaps due to the closeness he had with the Algerian war, or perhaps because he is constantly overlooking the arbitrary conditions of colonization, Fanon fails to fully show how a violent decolonization works. He states that "the native's violence unifies 
the people" (74), but he does not show how this happen exactly. Duckworth, which gives the title of the last song on $D A M N$., is Kendrick Lamar's last name, hence also his father's. Restating his claim that "what happens on Earth stays on earth" (DUCKWORTH), Lamar gives a powerful autobiographic monologue, which takes the form of a parable, on how the development of the "greatest rapper" (DUCKWORTH) emerges from a violent meeting between Lamar's father (Kenny "Ducky" Duckworth) and the founder of his label (Anthony "Top Dawg" Tiffith). While his father worked for a key chain restaurant, Anthony "Top Dawg" came inside while trying to escape from the police:

Ducky was well aware

They robbed the manager and shot a customer last year

He figured he'd get on these niggas' good sides

Free chicken every time Anthony posted in line

Two extra biscuits, Anthony liked him and then let him slide

They didn't kill him, in fact it look like they're the last to survive. (DUCKWORTH)

The question that opens DAMN. - "Is it wickedness?/Is it weakness" (BLOOD) echoes throughout DUCKWORTH, as it is the choice Anthony makes in a violent encounter that will have the highest influence on Lamar's destiny as an artist. Here Lamar takes his role as a prophet further and shows how wickedness is overcome, through a "good karma" (DUCKWORTH):

You take two strangers and put 'em in random predicaments

Give 'em a soul so they can make their own choices and live with it

Twenty years later, them same strangers, you make 'em meet again

Inside recording studios where they reapin' their benefits

Then you start remindin' them about that chicken incident

Whoever thought the greatest rapper would be from coincidence?

Because if Anthony killed Ducky, Top Dawg could be servin' life

While I grew up without a father and die in a gunfight. (DUCKWORTH)

It is only now, at the end of the album, that the listener has the opportunity to fully grasp the first song on DAMN. - BLOOD. The two narratives that constitute the most important violent encounters on the album - with the blind 
woman who shot him and the meeting between his father and Top Dawg; are, in fact, the pillars on which Lamar builds his monography on false prophets and fake gods, as well on what the United States represent today. What the father and the producer manage to achieve during their encounter (which could have had devastating effects on the lives of all three people involved) is the refusal "to surrender their agency to supreme acts of wickedness that too often define such a state of sinful existence" (Floyd-Thomas 91). The concept of 'agency' is what turns Lamar into a moralist, driving him towards an acceptance of his role as a prophet on DAMN. As Fanon states, "As far as the native is concerned, morality is very concrete; it is to silence the settler's defiance, to break his flaunting violence - in a word, to put him out of the picture" (Fanon 34). DUCKWORTH ends with the same line the album begins - "So I was taking a walk the other day" is a clear reminder of the fact that death can always remain a possibility and it is the personal choices that separate between life and death. The attempt Lamar makes towards silencing the white man takes the form of prophecy. He does not argue for a physical violence that will bring liberation, but rather he shows how the social context, personal decisions and collective failures can help perpetuate or destroy structural racism.

Despite the shortages and its many critiques, Fanon's writings provide a critical mechanism for understanding the dynamics at stake in confrontations that arise around racial separation, but also around social and political conditions that maintain the hegemonic duality of $I$ versus them. For Fanon, there is no way in which the colonizer and the colonized could live together. What Kendrick Lamar achieves on DAMN. is not the opposite of Fanonian thought, rather a different perspective on decolonization. Building on allegory, hyperbole and metaphor, Lamar shows how evil and wickedness are not located outside human existence as a whole, but they are constantly inside it. As Lamar is both the protagonist and antagonist on his album, he has the opportunity to look deep into both his and the other's evilness, while he faces the hidden darkness. Whiteness and Blackness do not exist independently of each other, but rather they co-inhabit a space of mutual violent acts. And this is precisely what DAMN. aims to show: rather than pursuing a binary mode of thinking and operating, it shows the confrontation between the meaning of whiteness and the construction of Blackness as a way of answering and understanding each other's humanity in a social, political and economic context that fails to offer salvation or redemption, but which still provides an open question: "You decide/Are we gonna live or 
die?" (BLOOD)

Re-writing, Re-imagining the Past (I)

\section{Works cited}

Fanon, Frantz. The Wretched of the Earth, transl. Constance Farrington. London: Penguin Group, 2001.

-, Black Skins, White Masks, transl. Charles Lam Markmann. London: Pluto Press, 2008.

Fairchild, Halford; "Frantz Fanon's The Wretched of the Earth in Contemporary Perspective". Journal of Black Studies, vol. 25, No. 2 (Dec., 1994): 191-199.

Floyd-Thomas, Juan. "The good, the m.A.A.d., and the holy: Kendrick Lamar's meditations on sin and moral agency in the post-gangsta era". Kendrick Lamar and the Making of Black Meaning. Oxon: Routledge, 2020: 69-98.

Lewellyn-Taylor, Ben; Jones, Melanie. "DAMNed of the earth. Kendrick Lamar, de/colonial violence, and earthbound salvation". Kendrick Lamar and the Making of Black Meaning. Oxon: Routledge, 2020: 245-62.

Metz, Johann Baptist. Faith in History and Society, transl. David Smith. New York: Seabury Press, 1980.

Pinn, Anthony, "Real nigga conditions. Kendrick Lamar, grotesque realism, and the open body". Kendrick Lamar and the Making of Black Meaning. Oxon: Routledge, 2020: 231-44.

Smith, R.C., "Fanon and the Concept of Colonial Violence". Black World/Negro Digest, 22:7, 1973: 23-33. 